\title{
Breast Cancer in African-American Women
}

\author{
Lisa A. Newman \\ University of Michigan, Ann Arbor, Michigan, USA
}

Key Words. Breast cancer $\cdot$ African-American women · Outcome disparities

\section{LeARning OBJECTIVES}

After completing this course, the reader will be able to:

1. Explain the differences in breast cancer incidence and mortality rates between African-American and CaucasianAmerican women.

2. Describe the patterns of breast cancer risk that are specific to African Americans, including age distribution and hormone receptor expression.

3. Discuss the potential limitations of breast cancer risk assessment for African-American women.

CME Access and take the CME test online and receive 1 hour of AMA PRA category 1 credit at $\underline{\text { CME.TheOncologist.com }}$

\begin{abstract}
African-American women face a lower risk of being diagnosed with breast cancer as compared to Caucasian-American women, yet they paradoxically face an increased breast cancer mortality hazard. An increased incidence rate for early-onset disease has
\end{abstract}

also been documented. This manuscript review summarizes the socioeconomic, environmental, genetic, and possible primary tumor biologic factors that may explain these disparities. The Oncologist 2005;10:1-14

\section{INTRODUCTION}

Breast cancer incidence is lower in African-American than in Caucasian-American women, yet breast cancer mortality rates are paradoxically higher for African-American women $[1,2]$. These poorly understood disparities have been consistently documented in population-based data from the Surveillance, Epidemiology, and End Results (SEER) program since its inception in 1976 [1, 2]. Another notable feature regarding ethnicity-related variation in the epidemiology of breast cancer is that African-American women face a greater risk for being diagnosed with earlyonset disease. This review summarizes the information available on the epidemiology of breast cancer in AfricanAmerican women, as well the possible socioeconomic, genetic, and primary tumor biologic factors that account for these variations.

\section{Clinical Epidemiology}

As shown in Figure 1, breast cancer incidence is lower for African-American than for Caucasian-American women, yet

Correspondence: Lisa A. Newman, M.D., M.P.H., F.A.C.S., Associate Professor of Surgery, Director, Breast Care Center, University of Michigan, 1500 East Medical Center Drive, 3308 CGC, Ann Arbor, Michigan 48109, USA. Telephone: 734936-8771; Fax: 734-647-9647; e-mail: lanewman@umich.edu Received April 27, 2004; accepted for publication July 21, 2004. CAlphaMed Press 1083-7159/2005/\$12.00/0 
Figure 1. Breast cancer incidence and mortality in African and Caucasian Americans.

the SEER program population-based data have documented higher breast cancer mortality rates among the AfricanAmerican community. The higher mortality rates are at least partially explained by the more advanced stage distribu-

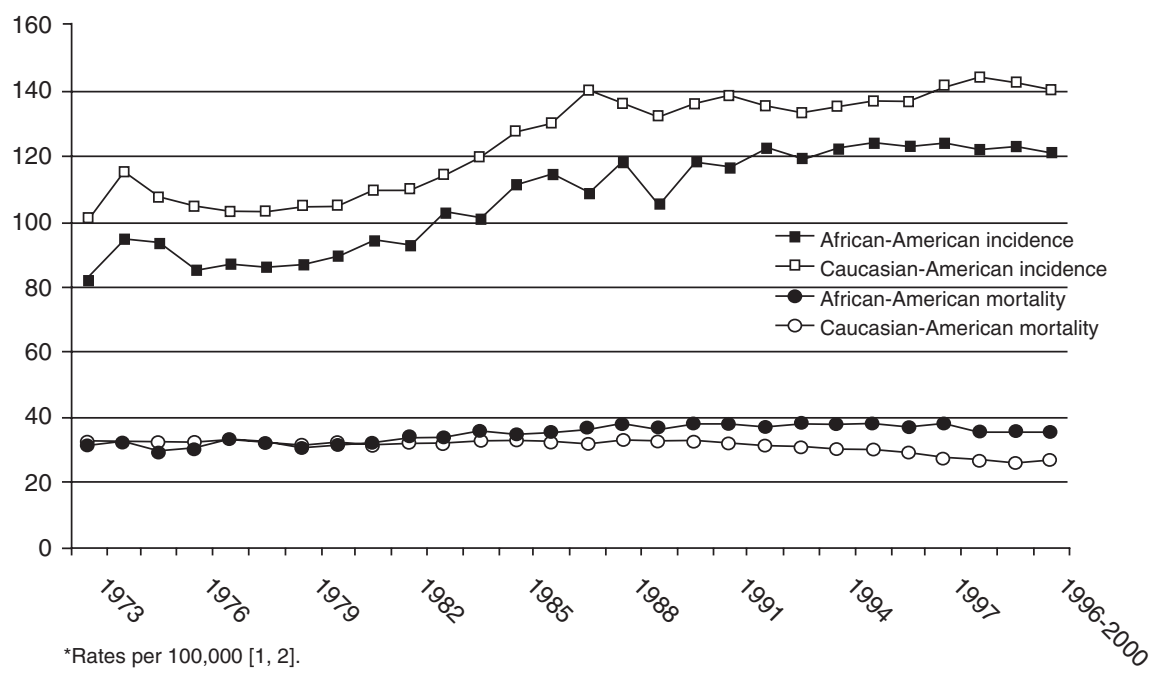
tion that is seen among African-American breast cancer patients, and these disparities are shown in Table $1[1,2]$.

The prevalence and strength of the established breast cancer risk factors among African-American women are not well documented, but some differences in the significance of various factors have been reported $[3,4]$ in analyses of the Contraceptives and Steroid Hormone (CASH) study. Mayberry and Stoddard-Wright [3] analyzed standard familial and gynecologic risk factors among breast cancer cases (3,934 Caucasian Americans, 490 African Americans) and controls (3,901 Caucasian Americans, 485 African Americans) from the CASH study and found that age at first live birth, parity, and surgical menopause had similar associations with breast cancer risk, but family history and age at menarche behaved differently as risk factors. For African Americans, first-degree and seconddegree family history of breast cancer had comparable strengths as risk factors (odds ratios, 1.61 and 1.71, respectively), whereas the association in Caucasian Americans was notably stronger in relation to the pattern of family history (odds ratio, 2.16 for first-degree relatives, and 1.44 for second-degree relatives). Relatively younger ages at menarche have also been reported for African-American women [5], but the impact of this finding on breast cancer incidence has not been defined.

An intriguing pattern of breast cancer in AfricanAmerican women is seen in the age-incidence curves for the disease, as demonstrated in Figure $2[1,2]$. Although breast cancer risk clearly increases as a function of age, AfricanAmerican women under the age of 45 years have a greater incidence of breast cancer than Caucasian-American women in this young age range. These rates equalize during the fifth decade of life, and for women over the age of 50 years, incidence rates for Caucasian Americans surpass those for African Americans, resulting in an overall higher lifetime risk for the Caucasian Americans. Although the absolute

values of these population-based incidence rates may not appear very large in magnitude, this ethnicity-related variation in age distribution is far more striking in clinical practice, where $20 \%$ of Caucasian-American breast cancer patients are younger than 50 years of age, compared with $30 \%-40 \%$ of African-American breast cancer patients [6].

It has been reported that the crossover in breast cancer age incidence between African-American and CaucasianAmerican women is a relatively recent phenomenon that evolved over the 1960s [7]. A sudden shift in age distribution is difficult to explain, making the accuracy of this observation dubious. The SEER program is the most well-established and comprehensive registry of population-based cancer data in the U.S., and case ascertainment for SEER began in 1974. One could easily speculate that research regarding the cancer burden among African Americans was inadequately documented during the first half of the twentieth century.

A plausible and interesting explanation for the younger age distribution of African-American breast cancer patients has been proposed by Pathak et al. [8]. Those investigators correlated the short-term increase in breast cancer risk that occurs in the postpartum period with premenopausal breast cancer risk. They hypothesized that the higher prevalence of early childbearing that is observed among AfricanAmerican compared with Caucasian-American women thereby accounts for the higher incidence of early-onset breast cancer. Palmer et al. [9] reported supporting data for this concept in an analysis of The Black Women's Health Study. Those investigators demonstrated a dual effect of pregnancy on breast cancer risk: multiparity increased breast cancer risk prior to the age of 45 years but was protective against breast cancer risk after age 45 .

Postmenopausal obesity is an established risk factor for breast cancer [10] because of the higher circulating estrogen 
Table 1. Results of selected studies comparing breast cancer in African-American and Caucasian-American women

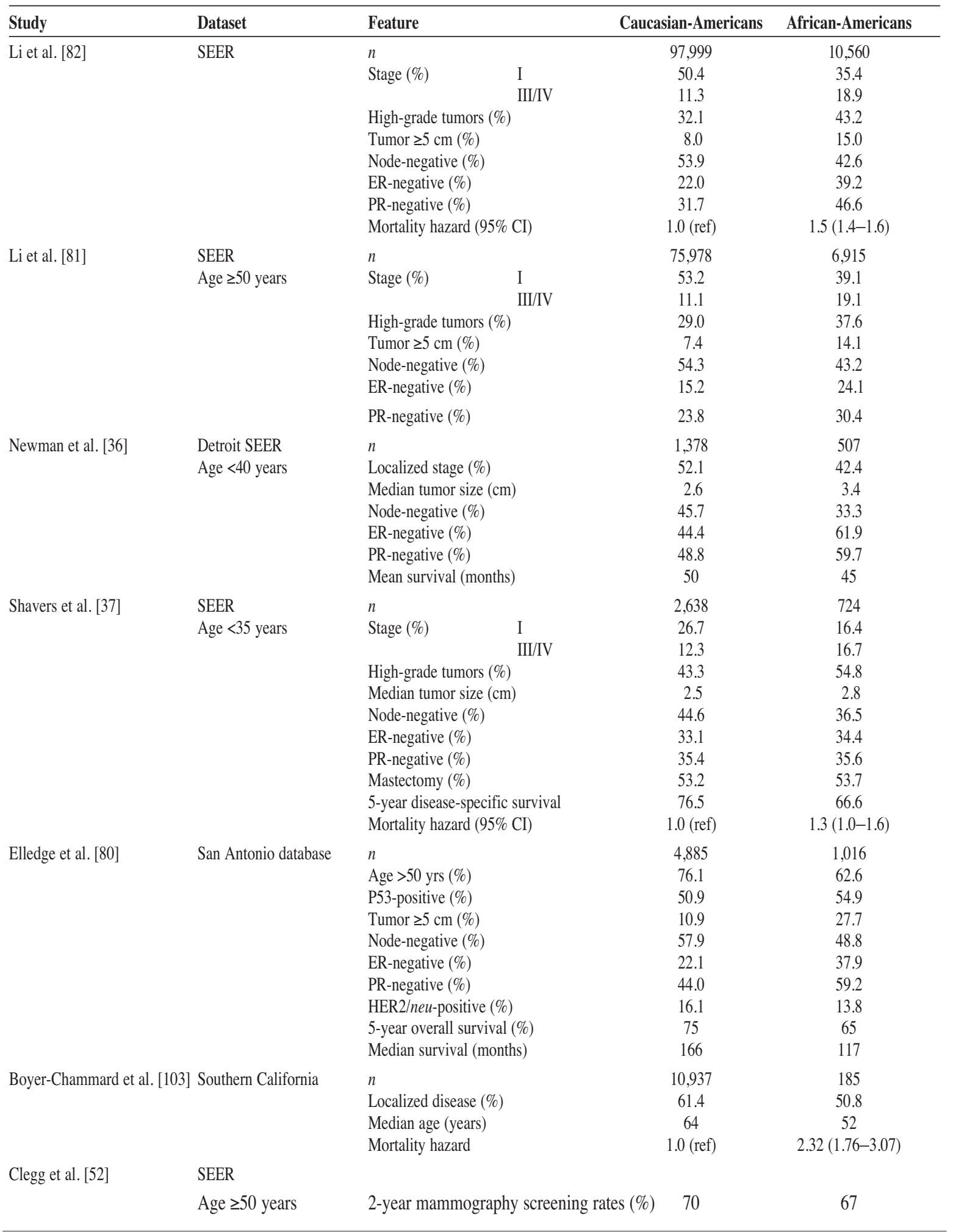

Abbreviations: $\mathrm{CI}=$ confidence interval; $\mathrm{ER}=$ estrogen receptor; $\mathrm{PR}=$ progesterone receptor

levels that result from fatty tissue metabolism of adrenal gland steroids in the absence of ovarian function. Flegal et al. [11] analyzed the Third National Health and Nutrition
Examination Survey (NHANES III) and found that more than half the African-American women over the age of 40 years were obese (body mass index $\geq 30$ ), and more than 


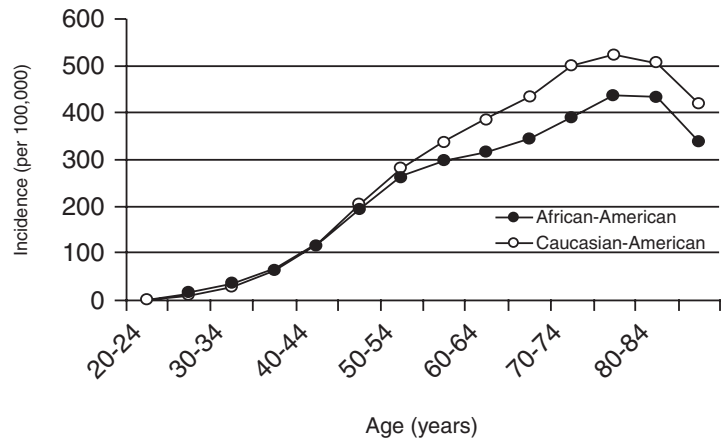

Figure 2. Age-incidence curves for breast cancer in African-American and Caucasian-American women.

$80 \%$ were overweight (body mass index $\geq 25$ ). However, as noted previously, breast cancer incidence rates are significantly lower for African-American women in the postmenopausal age range. The extent to which dietary fat contributes to breast cancer incidence among AfricanAmerican women is unclear at present. Other NHANES findings have implicated physical inactivity and inadequate intake of micronutrients, as well as other dietary components, as factors contributing to pre- and postmenopausal breast cancer risk among African-American women [12].

Breast cancer risk is a function of both environmental/ lifestyle exposures and genetic factors. It is therefore appropriate to compare patterns of the disease among African Americans with data regarding the epidemiology of breast cancer among native African women. Unfortunately, there is a paucity of population-based data regarding breast cancer incidence and mortality in Africa, a large continent comprised of many diverse nations. Nonetheless, available data reveal several provocative parallels between AfricanAmerican and native African breast cancer patients. Overall, breast cancer is a relatively unusual malignancy in African countries. Several investigators have documented a younger age distribution and a greater prevalence of highgrade, estrogen-receptor-negative disease among breast cancer patients in the Ghanaian and Nigerian populations of western Africa [13-16], similar to the patterns of breast cancer reported among African-American women. Western African populations served as the source for most of the slave trade to colonial North America, and therefore share a common ancestry with present-generation African Americans. These parallels suggest the possible contribution of founder effects.

\section{Molecular and Genetic Epidemiology}

Early studies of BRCA mutations suggested that they were relatively rare among African-American women [17]. Since that time, however, several BRCA-related breast cancers in African-American women have been identified [18-22], and these studies are reviewed comprehensively by Olopade et al. [23]. Germline mutations in the BRCA genes that are specifically associated with high-risk (but unrelated) AfricanAmerican kindreds have also been identified [18, 21, 23], and it is possible that additional African-associated founder mutations in other breast cancer susceptibility genes will be identified in the future. While population-based studies regarding the prevalence of mutations in breast cancer susceptibility genes are under way, no definitive data are available at present. Several reports have demonstrated that African-American women tend to underutilize genetic counseling services [24-26], and Matthews et al. [24] have underscored the importance of tailored outreach/educational strategies in order to improve the participation rates of African-American women in genetic counseling programs. Currently available data on genetic predisposition to breast cancer among African Americans are inadequate for drawing any conclusions regarding whether ethnicity-specific guidelines are warranted for identifying members of mutation-carrying kindreds. AfricanAmerican families appearing to be at high risk for harboring a BRCA mutation require complete gene sequencing.

Several investigators have confirmed an association between circulating levels of sex hormones and breast cancer risk [27-31]. Ethnicity-related variation in levels of endogenous hormones $[32,33]$ has also been reported, and this issue warrants further study. Bone density is one surrogate marker of estrogen levels, and it has been associated with a higher breast cancer risk. African-American women tend to be less susceptible to osteoporosis, and greater radial bone density has been correlated with breast cancer risk among African-American women by Nelson et al. [34]. Poola et al. [35] have shown that expression of the beta isoform in the estrogen receptor (which may be protective against abnormal proliferative changes in mammary epithelial tissue) may be disproportionately low in AfricanAmerican women. Studies thus far provide opportunities for speculation, but they fail to offer a clear picture of how hormone levels might account for the unique epidemiology of breast cancer in African-American women.

As shown in Table 1, the tumors of African-American breast cancer patients are significantly more likely to be hormone-receptor negative, aneuploid, and node positive. These patterns persist even after controlling for stage and age, as demonstrated in studies by Newman et al. [36] and Shavers et al. [37]. Furthermore, as biomedical research and genotyping tools develop further, contemporary studies are identifying other provocative characteristics that appear to be specific to African-American breast cancer patients. The results of several such studies, examining variations in cytochrome P450 
polymorphisms, estrogen receptor $\beta$, p53, and other markers, are shown in Table 2 . These latter observations require validation and expansion before their clinical relevance can be appropriately defined.

Table 2. Selected studies of primary tumor biology in African-American breast cancer patients, based on contemporary biomedical and molecular epidemiologic analyses

\begin{tabular}{|c|c|c|c|}
\hline Study & Sample size & Technology/Analysis & Findings \\
\hline Elledge et al. [80] & $\begin{array}{l}\text { 4,885 Caucasian-American breast } \\
\text { cancer patients } \\
1,016 \text { African-American breast } \\
\text { cancer patients } \\
777 \text { Hispanic-American breast } \\
\text { cancer patients }\end{array}$ & $\begin{array}{l}\text { Immunohistochemistry for ER/PR, } \\
\text { HER2/neu, p53; flow cytometry for } \\
\text { S-phase fraction and DNA ploidy status }\end{array}$ & $\begin{array}{l}\text { Tumors of African-American women } \\
\text { more likely to be hormone receptor } \\
\text { negative, with higher S-phase } \\
\text { fraction }\end{array}$ \\
\hline Shiao et al. [110] & $\begin{array}{l}47 \text { Caucasian-American breast } \\
\text { cancer patients } \\
45 \text { African-American breast } \\
\text { cancer patients }\end{array}$ & $\begin{array}{l}\text { PCR single-strand conformational } \\
\text { polymorphism analysis and DNA } \\
\text { sequencing }\end{array}$ & $\begin{array}{l}\text { Similar rates of somatic p53 } \\
\text { mutations, but specific alterations } \\
\text { varied between African-American } \\
\text { and Caucasian-American patients }\end{array}$ \\
\hline Guillemette et al. [111] & $\begin{array}{l}200 \text { African-American breast } \\
\text { cancer patients } \\
200 \text { African-American controls }\end{array}$ & Reverse transcriptase PCR analysis & $\begin{array}{l}\text { African-American-specific } \\
\text { polymorphisms in UG1A1, } \\
\text { a steroid-metabolizing gene }\end{array}$ \\
\hline Poola et al. [35] & $\begin{array}{l}24 \text { African-American breast } \\
\text { cancer patients }\end{array}$ & $\begin{array}{l}\text { Reverse transcriptase PCR to analyze } \\
\text { estrogen receptor isoforms }\end{array}$ & $\begin{array}{l}\text { Lower expression of estrogen } \\
\text { receptor- } \beta \text { and higher expression } \\
\text { of estrogen receptor- } \alpha \text { exon } 5 \Delta \\
\text { isoforms }\end{array}$ \\
\hline Mehrotra et al. [112] & $\begin{array}{l}44 \text { Caucasian-American breast } \\
\text { cancer patients } \\
67 \text { African-American breast } \\
\text { cancer patients }\end{array}$ & $\begin{array}{l}\text { Methylation-specific PCR to analyze } \\
\text { HIN-2; Twist; cyclin D-2; RASSFIA; } \\
\text { in situ hybridization PCR to analyze } \\
\text { HIN-1 mRNA }\end{array}$ & $\begin{array}{l}\text { Higher frequency of multiple gene } \\
\text { methylation in young African- } \\
\text { American women with estrogen } \\
\text { receptor-negative and progesterone } \\
\text { receptor-negative tumors }\end{array}$ \\
\hline Chen et al. [113] & $\begin{array}{l}149 \text { African-American women } \\
67 \text { Asian-American women } \\
226 \text { Caucasian-American women }\end{array}$ & $\begin{array}{l}\text { Computer-assisted measurements of } \\
\text { mammographic density in Asian- } \\
\text { American, African-American, and } \\
\text { Caucasian-American women }\end{array}$ & $\begin{array}{l}\text { Ethnic differences in breast density } \\
\text { correlated with ethnic variation in } \\
\text { risk require adjustment for age, body } \\
\text { mass index, and reproductive factors; } \\
\text { measurements of absolute density } \\
\text { are more meaningful than proportion } \\
\text { of dense tissue. }\end{array}$ \\
\hline Porter et al. [114] & $\begin{array}{l}124 \text { African-American breast } \\
\text { cancer patients } \\
397 \text { Caucasian-American breast } \\
\text { cancer patients }\end{array}$ & $\begin{array}{l}\text { Immunohistochemistry for ER/PR, } \\
\text { HER2/neu, Ki67, p53, cyclin E, } \\
\text { cyclin D1, p27, p16, pRb, and p21 }\end{array}$ & $\begin{array}{l}\text { Tumors of African-American women } \\
\text { more likely to be higher grade, and } \\
\text { associated with higher mitotic index, } \\
\text { ER/PR negativity, overexpression of } \\
\text { cyclin E, p16, and p53, and low expre- } \\
\text { ssion of cyclin D1 compared with } \\
\text { tumors of Caucasian-American women }\end{array}$ \\
\hline Millikan et al. [115] & $\begin{array}{l}760 \text { African-American breast } \\
\text { cancer patients } \\
1,265 \text { Caucasian-American breast } \\
\text { cancer patients }\end{array}$ & $\begin{array}{l}\text { Genotyping for manganese superoxide } \\
\text { dismutase Ala-9Val polymorphism }\end{array}$ & $\begin{array}{l}\text { Similar predictive value of polymor- } \\
\text { phism among African-American and } \\
\text { Caucasian-American breast cancer } \\
\text { patients; polymorphism only associ- } \\
\text { ated with breast cancer in cases with } \\
\text { smoking history, chest wall XRT, } \\
\text { and occupational radiation exposure }\end{array}$ \\
\hline Li et al. [116] & $\begin{array}{l}271 \text { African-American breast } \\
\text { cancer patients; } 285 \text { controls } \\
417 \text { Caucasian-American breast } \\
\text { cancer patients; } 417 \text { controls }\end{array}$ & $\begin{array}{l}\text { Genotyping for cytochrome P450 1A1 } \\
\text { (CYP1A1) polymorphisms }\end{array}$ & $\begin{array}{l}\text { Particular CYP } 1 \mathrm{~A} 1 \text { polymorphisms } \\
\text { associated with higher breast } \\
\text { cancer risk among smokers }\end{array}$ \\
\hline Jones [117] & $\begin{array}{l}177 \text { Caucasian-American breast } \\
\text { cancer patients } \\
145 \text { African-American breast } \\
\text { cancer patients }\end{array}$ & Immunohistochemistry for c-met, p53 & $\begin{array}{l}\text { Greater prevalence of } \mathrm{p} 53 \text { alter- } \\
\text { ations among African-American } \\
\text { women }\end{array}$ \\
\hline
\end{tabular}

Abbreviations: $\mathrm{ER}=$ estrogen receptor; $\mathrm{PR}$ = progesterone receptor; $\mathrm{PCR}=$ polymerase chain reaction; $\mathrm{XRT}$ = radiation therapy 


\section{Risk Assessment And Chemoprevention}

Risk assessment research has assumed an increased level of importance in light of the confirmed efficacy of tamoxifen [38], prophylactic mastectomy [39], and prophylactic oophorectomy [40] in reducing breast cancer incidence among high-risk women. The potential adverse events associated with all these risk-reducing strategies mandate the accurate identification of high-risk women for whom accepting the intervention-related hazards would be worthwhile.

Use of the selective estrogen-receptor modulator tamoxifen for chemoprevention is particularly relevant to a discussion of African Americans and breast cancer. Tamoxifen only reduces the risk of estrogen receptor-positive tumors, and African-American women have a relatively lower risk for being diagnosed with these favorable lesions. Furthermore, tamoxifen can cause thromboembolic phenomena, and morbidity from deep vein thrombosis/pulmonary emboli is relatively high among African-American women. On the other hand, tamoxifen-associated adverse events are uncommon among young women, and premenopausal African-American women face a higher risk for developing breast cancer. Unfortunately, only $1.7 \%$ of the National Surgical Adjuvant Breast Project (NSABP)P01 participants were African American [38], and we therefore have no data on efficacy of tamoxifen for pure chemoprevention in this population subset.

Freedman et al. [41] analyzed breast cancer risk factor data compiled by the year 2000 National Health Interview Survey Cancer Control Module in conjunction with the Gail tamoxifen benefit/risk index [42] to estimate the proportion of adult women in the U.S. who could benefit from tamoxifen therapy. For Caucasian-American women, 15.5\% would be eligible on the basis of risk estimates alone and $4.9 \%$ would have a favorable benefit/risk index. For African-American women, these rates were notably smaller in magnitude: $5.7 \%$ estimated to be risk eligible and $0.6 \%$ estimated to have a favorable benefit/risk index. The relatively low estimates for African-American women are disappointing in light of their known disproportionately elevated risk for breast cancer mortality. It should be noted, however, that the benefit/risk analysis accounts for a presumed greater risk for thromboembolism and stroke among African-American women (based on extrapolations from mortality data), but ethnicity-related differences in breast cancer mortality are not weighted into the index.

The incomplete understanding of risk factor exposures in African-American women has resulted in doubts regarding our ability to accurately predict breast cancer risk in this population subset via the established tools utilized for Caucasian-American women. The Gail breast cancer risk assessment model [43] allows for estimation of individualized likelihood of developing breast cancer. This model is a logistic regression equation based on risk factor data from participants of the Breast Cancer Detection and Demonstration Project, a mammography screening program conducted by the American Cancer Society during the 1970s. Very few African-American women participated in this program, and the model was, therefore, limited to risk factor exposure data from a case-control subset of the Caucasian participants, and in its original formulation it was appropriately labeled as a model to predict breast cancer risk in Caucasian-American women receiving annual mammographic screening. Risk estimates computed by this model are the primary means of determining eligibility for the NSABP chemoprevention trials, and so the model has been modified to adjust for risk calculations in African-American women as well.

The Gail model quantifies breast cancer risk by multiplying the relative risks for four different factors by the woman's age-specific baseline hazard for developing breast cancer. The model risk factors are age at menarche, age at first live birth, number of first-degree relatives with breast cancer, and number of breast biopsies. The age-specific baseline risk represents the absolute likelihood that a woman will develop breast cancer in the absence of increased risk conferred by the four model risk factors; this baseline is derived from SEER program age- and ethnicity-specific breast cancer incidence rates. The SEER program provides breast cancer incidence for the general population of women and a composite of various risk factor expressions. An approximation of the true baseline risk is extrapolated from these composite-risk incidence rates by subtracting the amount of disease that is estimated to have resulted from risk conferred by the four model risk factors (population attributable risk). Population attributable risk estimates are typically calculated from known data on risk factor prevalence rates.

The validity of the Gail model in accurately identifying groups of high-risk patients was demonstrated in three different populations of Caucasian-American women [44-47]. Recently, the model was evaluated in African-American women based on case-control data from the Women's Contraceptive and Reproductive Experiences study. This analysis suggested that the model tends to underestimate risk for African-American women and generated questions regarding accuracy of the baseline risk estimate component of the model, especially for the subset of young AfricanAmerican women [48, 49]. Utilization of a revised model with adjusted baseline risk estimates has been proposed.

\section{Early Detection and Screening}

The relatively more advanced stage distribution of breast cancer motivates the concern that African-American women receive suboptimal breast cancer surveillance. Widespread 
adoption of annual mammography screening practices since the 1970s among American women over the age of 40 years is credited for the recent improvements observed in population-based breast cancer outcome, as a direct consequence of increasing the proportion of screen-detected early-stage tumors [50]. SEER data reveal that between 1983 and 1998, the proportions of in situ and stage I disease doubled for the entire population [1]. As noted previously, however, AfricanAmerican women continue to present with greater proportions of advanced-stage disease, despite recent data indicating increases in mammography utilization among AfricanAmerican women that are comparable with utilization rates among Caucasian-American women, approaching 70\% [51]. Hence, the impact of screening patterns and follow-up in African-American women is incompletely understood.

The National Health Interview Survey (NHIS) utilizes specially trained U.S. Census Bureau personnel to collect health status and health care information on representative segments of the American population via personal household interviews conducted continuously since 1975. NHIS data reveal significant increases in utilization of mammography screening for both African Americans and Caucasian Americans since 1987. For women over 40 years of age, approximately one-quarter of both groups reported having had a mammogram within the past 2 years in 1987. In 2000, these rates increased to $71.4 \%$ for Caucasian Americans and $67.8 \%$ for African-American women. Interestingly, the disparity in mammography utilization is larger for women aged 40-49 years, where the rates are $67.1 \%$ for Caucasian and 60.9\% for African Americans [51-53].

The younger age distribution for breast cancer among African-American women leads to concerns regarding the efficacy of screening mammography, an imaging modality with limited accuracy in young women. This issue is not addressed in any of the original mammography screening trials because few African-American women were included in those phase III studies [54]. The international trials, by definition, would not have been expected to sample AfricanAmerican women, and the Health Initiatives Program of New York screening trial included fewer than 6\% AfricanAmerican participants. The paucity of data regarding surveillance mammography in African-Americans is reviewed by Royak-Schaler and Rose [55]. Jones et al. [56] reported that history of mammographic screening accounted for less than $10 \%$ of the higher risk for advanced-stage disease observed in a population-based study of breast cancer in African-American compared with Caucasian-American women from Connecticut. In contrast, McCarthy et al. [57] linked Medicare records on mammography claims with SEER data and found that history of mammography use accounted for $30 \%$ of the stage distribution disparity between older-aged African-American and Caucasian-American women. Patterson et al. [58] reported similar mammographic appearance for breast cancers detected in African-American compared with Caucasian-American women.

\section{EFFect of Socioeconomic Status (SES)}

In 1989, Freeman and Wasfie documented the powerful effects of African-American ethnicity combined with poverty on breast cancer outcome based on data from the Harlem Hospital Center [59]. That study reported a 39\% 5year survival rate for 512 surgically treated breast cancer patients between 1964 and 1986. Ninety-four percent of those patients were African American and only $6 \%$ presented with stage I disease, suggesting that few women in that system were undergoing mammographic screening for breast cancer. The Breast Examination Center of Harlem was established to address this health care deficit, and recently published findings [60] from that center demonstrate dramatic improvements in breast cancer stage distribution for the Harlem population. Between 1995 and 2000, nearly half the breast cancers detected were stage 0 or I disease.

Successful outreach and surveillance programs such as these suggest that ethnicity-related disparities in breast cancer survival can be reduced substantially by optimizing early detection with mammographic screening. However, national data have revealed a narrowing in the magnitude of difference for mammography utilization rates for AfricanAmerican compared with Caucasian-American women, and yet differences in stage distribution persist. It might, therefore, be inferred that outcome disparities will not be eliminated entirely by intensive screening efforts alone.

Socioeconomic factors probably account for a substantial proportion of breast cancer outcome disparities. As shown in Figure 3, poverty rates, likelihood of lacking medical insurance, and likelihood of relying on public insurance such as Medicaid are twice as high for African Americans

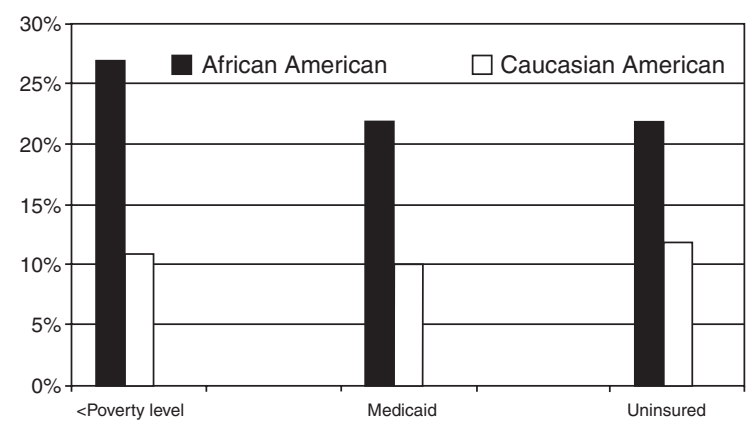

Figure 3. Proportions of African Americans compared with Caucasian Americans living below the poverty level, covered by Medicaid insurance, or completely uninsured [102]. 
compared with Caucasian Americans. These economic barriers to health care access certainly contribute to delays in breast cancer diagnosis and treatment, ultimately resulting in higher mortality rates.

Several studies have attempted to account for SES in evaluating ethnicity-related variation in breast cancer outcome. Findings from fourteen studies [61-74] published over the past 20 years were analyzed in a meta-analysis reported by Newman et al. [75]. Several patterns were apparent on careful scrutiny of these studies. First, socioeconomic disadvantages are more prevalent among African-American compared with Caucasian-American patients, as expected. Secondly, crude survival analyses demonstrate worse outcomes for the African-American breast cancer patients, which correlates with national population-based data from the SEER program. A third and final pattern is that adjustments to the survival analyses based on SES generally result in diminution or complete elimination of any statistically significant association with ethnicity. A necessary corollary to the adjusted survival comparisons is a reduction in the statistical power to evaluate ethnicity and SES, since the resulting comparison involves a relatively smaller subset of affluent AfricanAmerican breast cancer patients and a relatively larger subset of affluent Caucasian-American breast cancer patients. The pooled data yielded a more robust sample size, with more than 10,000 African-American and 40,000 Caucasian-American breast cancer patients contributing to the analysis. After adjusting for SES, stage, and age at diagnosis, a 22\% higher mortality risk was seen among the African-American patients (mortality odds ratio, 1.22; 95\% confidence interval: 1.131.30). The individual studies included in this meta-analysis evaluated other markers of tumor biology to varying degrees. Some studies included tumor grade, some included hormone receptor status, and others included histology in their adjusted, proportional hazards survival analyses. The summary data from the pooled analysis are shown in Figure 4.

Bradley et al. [76] published a recent report that underscores the complexities of SES and breast cancer survival analyses. Those investigators utilized Medicaid and census tract data linked to the Metropolitan Detroit SEER registry. African-American background was a predictor of worse outcome on univariate analysis; however, in the multivariate analysis that adjusted for residence in a high-poverty neighborhood (at least $5 \%$ of households below the poverty level), Medicaid coverage, stage, age, marital status, treatment, and disease stage retained the strongest significance levels independently. Notably, more than half the entire study population was categorized as residing in a lowincome neighborhood, and only $19 \%$ of the study population was African American. The sample size of AfricanAmerican breast cancer patients who were coded as not being poor was probably very small, and this study was therefore left with neither ethnicity nor SES retaining statistical significance. The authors nonetheless concluded that SES was probably the major determinant of poor outcome by leading to advanced stage at diagnosis.

As discussed in the meta-analysis, measures of SES are inconsistent and poorly validated. Furthermore, the prognostic value of SES is easily confounded by diet, lifestyle, and cultural factors, all of which may have ethnicity-based variations. Barriers to health care access secondary to poverty clearly exert a negative influence on breast cancer outcome. Quantifying the independent effects of SES, ethnicity, hereditary factors, and lifestyle/environmental exposures on breast tumor biology is therefore a formidable challenge.

\section{Treatment Effects}

Ethnicity-related variation in breast cancer treatment could influence outcome as a consequence of either A) inherent resistance to therapy related to primary disease factors or $\mathrm{B}$ ) inequalities in delivery of care. There is heterogeneity in breast tumor biology as well as in health care environments, and the individual breast cancer patient might therefore be impacted by either, both, or neither of these factors.

Locoregional recurrence rates tend to be higher in younger breast cancer patients treated by lumpectomy. The younger age distribution of African-American breast cancer patients therefore warrants a closer look at outcome following breast conservation therapy (BCT). Several studies (Table 3) have, therefore, evaluated BCT in AfricanAmerican and Caucasian-American breast cancer patients. As reviewed by Newman et al. [77], overall BCT utilization rates are relatively low for both patient populations, and

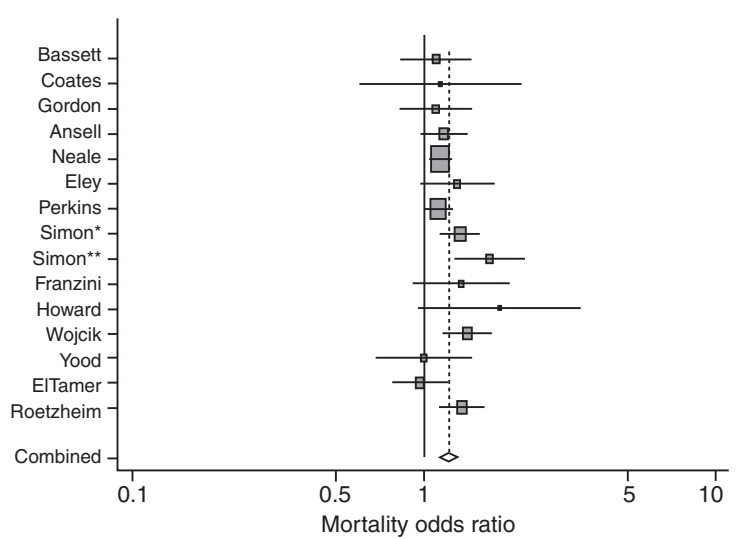

Figure 4. Meta-analysis of studies comparing outcome from breast cancer in African-American $(n=10,001)$ and Caucasian-American $(n=42,473)$ patients, after adjusting for age, stage, and SES. Mortality odds ratio 1.22 ; $95 \%$ confidence interval 1.13-1.30. $*$ Patients $<50$ years of age. $* *$ Patients $\geq 50$ years of age [75]. 
Table 3. Selected studies of breast conservation therapy in African-American women

\begin{tabular}{|c|c|c|c|c|c|}
\hline \multirow[b]{2}{*}{ Study } & \multicolumn{2}{|c|}{$n$ of patients } & \multirow[b]{2}{*}{ Study criteria } & \multirow[b]{2}{*}{ Median follow-up } & \multirow[b]{2}{*}{ Findings } \\
\hline & $\begin{array}{l}\text { African } \\
\text { American }\end{array}$ & Caucasian & & & \\
\hline Burri et al. [104] & 72 & 29 & $\begin{array}{l}\text { All BCT cases; mostly } \\
\text { indigent population }\end{array}$ & $\begin{array}{l}\text { Estimated } \\
5 \text { years }\end{array}$ & $\begin{array}{l}\text { Local control for African-American patients } \\
95.2 \% \text { at } 5 \text { years; } 87.9 \% \text { at } 10 \text { years; } \\
\text { Disease-free survival rate for African-American } \\
\text { patients } 84.6 \% \text { at } 5 \text { years; } 65.3 \% \text { at } 10 \text { years. }\end{array}$ \\
\hline Connor et al. [105] & 71 & 204 & $\begin{array}{l}\text { Stage I/II; all treated } \\
\text { with BCT }\end{array}$ & 53 months & $\begin{array}{l}\text { Trend for higher local recurrence rate in } \\
\text { African Americans (n.s.) }\end{array}$ \\
\hline Nicolaou et al. [106] & 41 & 301 & $\begin{array}{l}\text { Stage IIA/B; node } \\
\text { positive; all treated } \\
\text { with BCT }\end{array}$ & 73 months & $\begin{array}{l}\text { Higher regional relapse rate among African } \\
\text { Americans (19\% versus } 1 \% ; p<0.0001 \text { ) }\end{array}$ \\
\hline Velanovich et al. [107] & 416 & 834 & $\begin{array}{l}\text { Stages I-IV; treatment } \\
\text { variable }\end{array}$ & NA & $\begin{array}{l}\text { Similar rates of BCT among African-American } \\
\text { and Caucasian-American patients (54.5\% } \\
\text { versus } 57.2 \%)\end{array}$ \\
\hline Newman et al. [78] & 211 & NA & $\begin{array}{l}\mathrm{T} 1 / \mathrm{T} 2 \text { tumors; } \\
\text { treatment variable }\end{array}$ & 68 months & $\begin{array}{l}\text { BCT rate } 19.9 \% \\
\text { Similar local recurrence and survival rates } \\
\text { in BCT and mastectomy patients }(9.8 \% \\
\text { versus } 8.9 \%)\end{array}$ \\
\hline Arnold et al. [108] & 107 & 131 & $\begin{array}{l}\text { All treated in an urban } \\
\text { teaching hospital }\end{array}$ & NA & $\begin{array}{l}\text { BCT rate } 36 \% \text { for African-Americans; } 41 \% \\
\text { for Caucasian-American patients }\end{array}$ \\
\hline Muss et al. [109] & 160 & 145 & $\begin{array}{l}\text { Stage II; node positive; } \\
\text { treatment variable }\end{array}$ & NA & $\begin{array}{l}\text { Lower BCT rates among African-American } \\
\text { than among Caucasian-Americans patients } \\
\text { ( } 22 \% \text { versus } 40 \% ; p=0.004 \text { ) }\end{array}$ \\
\hline Pierce et al. [79] & 75 & 615 & $\begin{array}{l}\text { Stage I/II; all treated } \\
\text { with BCT }\end{array}$ & 56 months & $\begin{array}{l}\text { Similar local recurrence rates for African- } \\
\text { American and Caucasian-Americans patients } \\
(5 \% \text { versus } 6 \%) \text {; higher regional relapse rates } \\
\text { for African-American patients ( } 16 \% \text { versus } \\
4 \% ; p=0.001 \text { ) }\end{array}$ \\
\hline
\end{tabular}

Abbreviation: n.s. $=$ not significant

although some data indicate a higher risk of local recurrence for African-American women, this may be related to underlying tumor biology, as the risk of local recurrence is greater following mastectomy as well [78]. Some interesting patterns of locoregional and distant failure following BCT were reported by Pierce et al. [79] in a study of BCT in 75 AfricanAmerican and 615 Caucasian-American breast cancer patients. Local-only recurrence was similarly low for both subsets of patients (5\% and 6\%, respectively), but the risks of regional failure (especially in the supraclavicular nodal basin) and distant metastases were significantly higher for the African-American patients.

As noted previously, African-American breast cancer patients are more likely to have estrogen receptor-negative disease [36, 37, 80-82]. This variation clearly influences cancer management, as endocrine therapy is contraindicated and replaced by chemotherapy as the only option for adjuvant systemic treatment for these estrogen receptornegative tumors. For African-American patients with estrogen receptor-positive tumors, however, hormonal therapy with tamoxifen appears to have equivalent efficacy to when delivered to Caucasian-American breast cancer patients, as demonstrated by McCaskill-Stevens et al. [83] in a pooled analysis of NSABP adjuvant therapy studies. Nonetheless, population-based data on comorbidities raise some interesting questions with regard to selection of endocrine therapy. As noted previously, thromboembolism is relatively more prevalent among African Americans and is also a known potential complication of tamoxifen therapy. Aromatase inhibitors have a lower risk of exacerbating thromboembolic problems but pose a risk of accelerated osteoporosis [84]. African-American women tend to have a lower risk of osteoporotic bones than Caucasian-American women. One might, therefore, postulate that aromatase inhibitors would be the preferred hormonal therapy for postmenopausal African-American women diagnosed with estrogen receptor-positive breast cancer. Unfortunately, there are no published data on efficacy and side effects of aromatase inhibitors in African-American women.

Chemosensitivity of breast cancer in African Americans has been studied indirectly. Growing work in the area of pharmacogenetics is resulting in the identification of various 
polymorphisms in proteins that are involved with metabolism of cancer-treating therapies. Polymorphisms in cytochrome P450/CYP enzymes are known to have variable prevalence rates among different ethnically defined subsets of the population $[85,86]$ and could potentially alter chemotherapy effectiveness. Review of the MD Anderson locally advanced breast cancer database, however, revealed similar clinical and pathologic response rates to induction chemotherapy for African-American and CaucasianAmerican breast cancer patients [87].

A provocative study, reported by Hershman et al. [88], demonstrated that African-American breast cancer patients were more likely to experience delays in completion of adjuvant chemotherapy regimens related to neutropenia, and that this prolongation of treatment may correlate with a lower overall dose intensity. Interestingly, the clinical relevance of ethnicity-related neutropenia is poorly understood, as baseline neutrophil counts were lower among the African-American patients, and this hematologic pattern has been noted among the general population as well. The potential confounding effect of obesity rates among African-American breast cancer patients and its impact on chemotherapy dosing also requires further study.

Unfortunately, disparities in delivery of treatment to African-American breast cancer patients have also been reported [89], raising the concern that discriminatory practices in the health care system may also contribute to outcome disparities. These disparities may be unintentional and related to miscommunication between patient and health care provider or they may be related to socioeconomic issues. Chu et al. [90] reported that the magnitude of difference in breast cancer outcome between AfricanAmerican and Caucasian-American patients was minimized among women age 65 or older, and the authors interpreted their findings as implying that more effective breast cancer treatment was delivered to women who were more likely to have health care coverage by virtue of being age eligible for Medicare benefits. Breen et al. [89] found evidence of unequal breast cancer management in a subset analysis conducted on participants of the Black/White Cancer Survival Study, where $21 \%$ of African-American patients failed to receive the minimum expected standard of care (as defined by National Cancer Institute consensus statements), compared with $15 \%$ of Caucasian-American patients.

Standardization of care through the clinical trials mechanism would be expected to abolish the influence of ethnicityrelated treatment and/or socioeconomic disparities on breast cancer outcome, thereby providing a "pure" assessment of ethnicity-related survival. Roach et al. [91] examined breast cancer survival among African-American and CaucasianAmerican participants of a Cancer and Leukemia Group B phase III study of node-positive disease and found a worse outcome for the African Americans in a univariate analysis. The investigators were able to eliminate the statistical significance of this association by performing a multivariate logistic regression analysis that included age, hormonereceptor expression, number of metastatic nodes, and chemotherapy dose. This latter analysis was clearly affected by progressive loss of statistical power related to small subset sample sizes.

Subset analyses of NSABP trials have yielded inconsistent results regarding the influence of ethnic background on outcome. An early analysis of outcome predictors for the NSABP B-06 trial revealed worse survival for AfricanAmerican participants [92]. In contrast, more recent reviews of the NSABP protocols reported by Dignam [93, 94] revealed that, after accounting for other primary tumor features, African-American ethnicity was generally not an independent predictor of worse disease-free outcome. Overall mortality rates, however, were significantly higher for African Americans, suggesting that comorbidities may be exerting an effect.

Albain et al. [95] conducted one of the most recent and powerful studies presented to date on the issue of ethnicityrelated breast cancer outcome within the context of the clinical trials setting. The Southwest Oncology Group pooled the data on all breast cancer patients (nearly 7,000 cases) participating in five prospective, randomized, adjuvant therapy clinical trials conducted between 1975 and 1995 . Albain et al. analyzed survival for these studies (consisting of approximately 10\% African-American patients) after adjusting for SES, age, and disease stage. They found that African-American ethnicity was a statistically significant and independent predictor of mortality risk in the multivariate survival analyses of both pre- and postmenopausal breast cancer patients. Hazard ratios for mortality in the overall survival analysis were 1.41 (95\% confidence interval, 1.10-1.82) for premenopausal African-American women and 1.49 (95\% confidence interval, 1.28-1.73) for postmenopausal African-American women. Similar statistically significant outcome disadvantages were reported for disease-free survival.

\section{Future Directions}

As biomedical technology and techniques of molecular epidemiology continue to mature, we are likely to gain improved insight regarding modifiable versus fixed determinants of breast cancer risk as well as treatment response. However, it will be incumbent upon the oncology research community to design studies that account for ethnic ancestry to the greatest extent possible, so that ethnicity-related variations can be defined. The health care provider 
community must assume responsibility for implementing outreach programs that optimize African-American participation in genetic counseling programs, breast cancer screening programs, and treatment, as well as chemoprevention clinical trials. These efforts will strengthen the likelihood of successful research endeavors. The importance of survivor advocates, social networks, and church-based support groups appears to be quite valuable in achieving the outreach goals [96-100]. In particular, cancer care providers should be aware of the Sisters Network, Inc., a national African-American survivor advocate organization that has provided breast health awareness information and clinical trials support to thousands of women in the African-American community since its inception in 1994 [101]. Information regarding the support services and resources offered by this organization is available at their website, www.sistersnetwork.com.

\section{Summary}

Breast cancer pathogenesis and epidemiology are complex and influenced by the myriad of environmental and lifestyle factors that impact on lifetime hormone exposures. The genetic, socioeconomic, and cultural features associated with ethnic background complicate the picture further. For AfricanAmerican women these various elements converge to yield the paradoxical patterns of a relatively lower breast cancer incidence, higher mortality rate, and younger age distribution. Expanded breast cancer screening programs and attention to assuring equality in delivery of care should result in some degree of improved outcome. It is also essential to ensure increased accrual of African Americans into chemoprevention as well as treatment trials. As microarray technology to evaluate the genetic composition of tumors becomes more widely available, many of the questions regarding ethnicity-associated variation in primary cancer biology will be clarified.

\section{REFERENCES}

1 Ries L, Eisner M, Kosary M. SEER Cancer Statistics Review, 1973-1999. Bethesda, MD: National Cancer Institute, 2002.

2 Ries L, Eisner M, Kosary M. SEER Cancer Statistics Review, 1975-2000. Bethesda, MD: National Cancer Institute, 2003.

3 Mayberry RM, Stoddard-Wright C. Breast cancer risk factors among black women and white women: similarities and differences. Am J Epidemiol 1992;136:1445-1456.

4 Mayberry RM. Age-specific patterns of association between breast cancer and risk factors in black women, ages 20 to 39 and 40 to 54. Ann Epidemiol 1994;4:205-213.

5 Bernstein L, Teal CR, Joslyn S et al. Ethnicity-related variation in breast cancer risk factors. Cancer 2003;97:222-229.

6 National Cancer Data Base. Patterns of diagnosis and treatment, 1995-2000. National Cancer Database. http://web.facs.org/ ncdbbmr/ncdbbenchmarks.cfm. Accessed August, 2004.

7 Krieger N. Social class and the black/white crossover in the age-specific incidence of breast cancer: a study linking census-derived data to population-based registry records. Am J Epidemiol 1990;131:804-814.

8 Pathak DR, Osuch JR, He J. Breast carcinoma etiology: current knowledge and new insights into the effects of reproductive and hormonal risk factors in black and white populations. Cancer 2000;88(suppl):1230-1238.

9 Palmer JR, Wise LA, Horton NJ et al. Dual effect of parity on breast cancer risk in African-American women. J Natl Cancer Inst 2003;95:478-483.

10 Colditz GA, Rosner B. Cumulative risk of breast cancer to age 70 years according to risk factor status: data from the Nurses' Health Study. Am J Epidemiol 2000;152:950-964.

11 Flegal KM, Carroll MD, Ogden CL et al. Prevalence and trends in obesity among US adults, 1999-2000. JAMA 2002;288:1728-1732.
12 Forshee RA, Storey ML, Ritenbaugh C. Breast cancer risk and lifestyle differences among premenopausal and postmenopausal African-American women and white women. Cancer 2003;97(suppl):280-288.

13 Ijaduola TG, Smith EB. Pattern of breast cancer among white-American, African-American, and nonimmigrant west-African women. J Natl Med Assoc 1998;90:547-551.

14 Ihekwaba FN. Breast cancer in Nigerian women. Br J Surg 1992;79:771-775.

15 Ikpatt OF, Kuopio T, Collan Y. Proliferation in African breast cancer: biology and prognostication in Nigerian breast cancer material. Mod Pathol 2002;15:783-789.

16 Ikpatt OF, Kuopio T, Ndoma-Egba R et al. Breast cancer in Nigeria and Finland: epidemiological, clinical and histological comparison. Anticancer Res 2002;22:3005-3012.

17 Newman B, Mu H, Butler LM et al. Frequency of breast cancer attributable to BRCA1 in a population-based series of American women. JAMA 1998;279:915-921.

18 Gao Q, Neuhausen S, Cummings S et al. Recurrent germ-line BRCA1 mutations in extended African American families with early-onset breast cancer. Am J Hum Genet 1997;60:12331236.

19 Gao Q, Tomlinson G, Das S et al. Prevalence of BRCA1 and BRCA2 mutations among clinic-based African American families with breast cancer. Hum Genet 2000;107:186-191.

20 Dangel J, Wagner-Costalas J, Bove B et al. Novel germline BRCA1 mutation (155del4) in an African American with early-onset breast cancer. Hum Mutat 1999;14:545.

21 Mefford HC, Baumbach L, Panguluri RC et al. Evidence for a BRCA1 founder mutation in families of West African ancestry. Am J Hum Genet 1999;65:575-578.

22 Arena J, Smith S, Plewinska M. BRCA1 mutations in African American women. Am J Hum Genet 1996;9:34. 
23 Olopade OI, Fackenthal JD, Dunston G et al. Breast cancer genetics in African Americans. Cancer 2002;97:236-245.

24 Matthews A, Cummings S, Thompson S et al. Genetic testing of African Americans for susceptibility to inherited cancers: use of focus groups to determine factors contributing to participation. J Psychosoc Oncol 2000;18:1-19.

25 Lerman C, Hughes C, Benkendorf J et al. Racial differences in testing motivation and psychological distress following pretest education for BRCA1 gene testing. Cancer Epidemiol Biomarkers Prev 1999;8:361-367.

26 Hughes C, Gomez-Caminero A, Benkendorf J et al. Ethnic differences in knowledge and attitudes about BRCA1 testing in women at increased risk. Patient Educ Couns 1997;32:51-62.

27 Cummings SR, Duong T, Kenyon E et al. Serum estradiol level and risk of breast cancer during treatment with raloxifene. JAMA 2002;287:216-220.

28 Hankinson SE, Willett WC, Manson JE et al. Plasma sex steroid hormone levels and risk of breast cancer in postmenopausal women. J Natl Cancer Inst 1998;90:1292-1299.

29 Key TJ, Appleby PN, Reeves GK et al. Body mass index, serum sex hormones, and breast cancer risk in postmenopausal women. J Natl Cancer Inst 2003;95:1218-1226.

30 Zeleniuch-Jacquotte A, Shore RE, Koenig KL et al. Postmenopausal levels of oestrogen, androgen, and SHBG and breast cancer: long-term results of a prospective study. Br J Cancer 2004;90:153-159.

31 Sturgeon SR, Potischman N, Malone KE et al. Serum levels of sex hormones and breast cancer risk in premenopausal women: a case-control study (USA). Cancer Causes Control 2004; 15:45-53.

32 Randolph JF Jr, Sowers M, Bondarenko IV et al. Change in estradiol and follicle-stimulating hormone across the early menopausal transition: effects of ethnicity and age. J Clin Endocrinol Metab 2004;89:1555-1561.

33 Lasley BL, Santoro N, Randolf JF et al. The relationship of circulating dehydroepiandrosterone, testosterone, and estradiol to stages of the menopausal transition and ethnicity. J Clin Endocrinol Metab 2002;87:3760-3767.

34 Nelson DA, Darga LL, Simon MS et al. Radial bone density and breast cancer risk in white and African-American women. Osteoporos Int 2004;15:535-540.

35 Poola I, Clarke R, DeWitty R et al. Functionally active estrogen receptor isoform profiles in the breast tumors of African American women are different from the profiles in breast tumors of Caucasian women. Cancer 2002;94:615-623.

36 Newman LA, Bunner S, Carolin K et al. Ethnicity related differences in the survival of young breast carcinoma patients. Cancer 2002;95:21-27.

37 Shavers VL, Harlan LC, Stevens JL. Racial/ethnic variation in clinical presentation, treatment, and survival among breast cancer patients under age 35. Cancer 2003;97:134-147.

38 Fisher B, Costantino JP, Wickerham DL et al. Tamoxifen for prevention of breast cancer: report of the National Surgical Adjuvant Breast and Bowel Project P-1 Study. J Natl Cancer Inst 1998;90:1371-1388.
39 Hartmann LC, Schaid DJ, Woods JE et al. Efficacy of bilateral prophylactic mastectomy in women with a family history of breast cancer. N Engl J Med 1999;340:77-84.

40 Rebbeck TR, Levin AM, Eisen A et al. Breast cancer risk after bilateral prophylactic oophorectomy in BRCA1 mutation carriers. J Natl Cancer Inst 1999;91:1475-1479.

41 Freedman A, Graubard B, Rao S et al. Estimates of the number of U.S. women who could benefit from tamoxifen for breast cancer chemoprevention. J Natl Cancer Inst 2003;95:526-532.

42 Gail M, Costantino J, Bryant J et al. Weighing the risks and benefits of tamoxifen treatment for preventing breast cancer. J Natl Cancer Inst 1999;91:1829-1846.

43 Gail MH, Brinton LA, Byar DP et al. Projecting individualized probabilities of developing breast cancer for white females who are being examined annually. J Natl Cancer Inst 1989;81:1879-1886.

44 Bondy ML, Lustbader ED, Halabi S et al. Validation of a breast cancer risk assessment model in women with a positive family history. J Natl Cancer Inst 1994;86:620-625.

45 Rockhill B, Spiegelman D, Byrne C et al. Validation of the Gail et al. model of breast cancer risk prediction and implications for chemoprevention. J Natl Cancer Inst 2001;93:358-366.

46 Spiegelman D, Colditz GA, Hunter D et al. Validation of the Gail et al. model for predicting individual breast cancer risk. J Natl Cancer Inst 1994;86:600-607.

47 Costantino JP, Gail M, Pee D et al. Validation studies for models projecting the risk of invasive and total breast cancer incidence. J Natl Cancer Inst 1999;91:1541-1548.

48 Newman LA, Rockhill B, Bondy ML et al. Validation of the Gail Breast Cancer risk assessment model in African American women based on a multi-center case-control study of 3,283 African American and 5,974 White American women. Proc Am Soc Clin Oncol 2002;21:976.

49 Newman LA, Gail MH, Selvan M et al. Proposed revision of the Gail breast cancer risk assessment model for African American women. Proc Am Soc Clin Oncol 2003;22:52.

50 Feig SA. Effect of service screening mammography on population mortality from breast carcinoma. Cancer 2002;95:451-457.

51 Ward E, Jemal A, Cokkinides V et al. Cancer disparities by race/ethnicity and socioeconomic status. CA Cancer J Clin 2004;54:78-93.

52 Clegg LX, Li FP, Hankey BF et al. Cancer survival among US whites and minorities: a SEER (Surveillance, Epidemiology, and End Results) Program population-based study. Arch Intern Med 2002;162:1985-1993.

53 National Health Interview Survey. Mammography utilization, NHIS Website. http://www.cdc.gov/nchs/nhis.htm. Accessed August 2004.

54 Humphrey L, Helfand M, Chan B et al. Breast cancer screening: a summary of the evidence. Ann Intern Med 2004;137:344-346.

55 Royak-Schaler R, Rose DP. Mammography screening and breast cancer biology in African American women-a review. Cancer Detect Prev 2002;26:180-191. 
56 Jones BA, Kasl SV, Curnen MG et al. Can mammography screening explain the race difference in stage at diagnosis of breast cancer? Cancer 1995;75:2103-2113.

57 McCarthy EP, Burns RB, Coughlin SS et al. Mammography use helps to explain differences in breast cancer stage at diagnosis between older black and white women. Ann Intern Med 1998;128:729-736.

58 Patterson SK, Helvie MA, Joynt LK et al. Mammographic appearance of breast cancer in African-American women: report of 100 consecutive cases. Acad Radiol 1998;5:2-8.

59 Freeman HP, Wasfie TJ. Cancer of the breast in poor black women. Cancer 1989;63:2562-2569.

60 Liberman L, Freeman H, Chandra S et al. Carcinoma detection at the Breast Examination Center of Harlem. Cancer 2002;95:8-14.

61 Bassett MT, Krieger N. Social class and black-white differences in breast cancer survival. Am J Public Health 1986;76:1400-1403.

62 Coates RJ, Clark WS, Eley JW et al. Race, nutritional status, and survival from breast cancer. J Natl Cancer Inst 1990;82:1684-1692.

63 Gordon NH, Crowe JP, Brumberg DJ et al. Socioeconomic factors and race in breast cancer recurrence and survival. Am J Epidemiol 1992;135:609-618.

64 Ansell D, Whitman S, Lipton R et al. Race, income, and survival from breast cancer at two public hospitals. Cancer 1993;72:2974-2978.

65 Neale AV. Racial and marital status influences on 10 year survival from breast cancer. J Clin Epidemiol 1994;47:475-483.

66 Eley JW, Hill HA, Chen VW et al. Racial differences in survival from breast cancer. Results of the National Cancer Institute Black/White Cancer Survival Study. JAMA 1994;272:947-954.

67 Perkins P, Cooksley CD, Cox JD. Breast cancer. Is ethnicity an independent prognostic factor for survival? Cancer 1996;78:1241-1247.

68 Simon MS, Severson RK. Racial differences in survival of female breast cancer in the Detroit metropolitan area. Cancer 1996;77:308-314.

69 Franzini L, Williams AF, Franklin J et al. Effects of race and socioeconomic status on survival of 1,332 black, Hispanic, and white women with breast cancer. Ann Surg Oncol 1997;4:111-118.

70 Howard DL, Penchansky R, Brown MB. Disaggregating the effects of race on breast cancer survival. Fam Med 1998;30:228-235.

71 Wojcik BE, Spinks MK, Optenberg SA. Breast carcinoma survival analysis for African American and white women in an equal-access health care system. Cancer 1998;82:1310-1318.

72 Yood MU, Johnson CC, Blount A et al. Race and differences in breast cancer survival in a managed care population. J Natl Cancer Inst 1999;91:1487-1491.
73 El-Tamer MB, Homel P, Wait RB. Is race a poor prognostic factor in breast cancer? J Am Coll Surg 1999;189:41-45.

74 Roetzheim RG, Gonzalez EC, Ferrante JM et al. Effects of health insurance and race on breast carcinoma treatments and outcomes. Cancer 2000;89:2202-2213.

75 Newman LA, Mason J, Cote D et al. African-American ethnicity, socioeconomic status, and breast cancer survival: a metaanalysis of 14 studies involving over 10,000 African-American and 40,000 White American patients with carcinoma of the breast. Cancer 2002;94:2844-2854.

76 Bradley CJ, Given CW, Roberts C. Race, socioeconomic status, and breast cancer treatment and survival. J Natl Cancer Inst 2002;94:490-496.

77 Newman LA, Theriault R, Clendinnin $\mathrm{N}$ et al. Treatment choices and response rates in African-American women with breast carcinoma. Cancer 2003;97:246-252.

78 Newman LA, Kuerer HM, Hunt KK et al. Local recurrence and survival among black women with early-stage breast cancer treated with breast-conservation therapy or mastectomy. Ann Surg Oncol 1999;6:241-248.

79 Pierce L, Fowble B, Solin LJ et al. Conservative surgery and radiation therapy in black women with early stage breast cancer. Patterns of failure and analysis of outcome. Cancer 1992;69:2831-2841.

80 Elledge RM, Clark GM, Chamness GC et al. Tumor biologic factors and breast cancer prognosis among white, Hispanic, and black women in the United States. J Natl Cancer Inst 1994;86:705-712.

81 Li CI, Malone KE, Daling JR. Differences in breast cancer hormone receptor status and histology by race and ethnicity among women 50 years of age and older. Cancer Epidemiol Biomarkers Prev 2002;11:601-607.

82 Li CI, Malone KE, Daling JR. Differences in breast cancer stage, treatment, and survival by race and ethnicity. Arch Intern Med 2003;163:49-56.

83 McCaskill-Stevens W, Bryant J, Costantino J et al. Incidence of contralateral breast cancer (CBC), endometrial cancer (EC), and thromboembolic events (TE) in African American women receiving tamoxifen for treatment of primary breast cancer. Am Soc Clin Oncol 2000:269a.

84 Baum M, Budzar AU, Cuzick J et al. Anastrozole alone or in combination with tamoxifen versus tamoxifen alone for adjuvant treatment of postmenopausal women with early breast cancer: first results of the ATAC randomised trial. Lancet 2002;359:2131-2139.

85 Xie HG, Prasad HC, Kim RB et al. CYP2C9 allelic variants: ethnic distribution and functional significance. Adv Drug Deliv Rev 2002;54:1257-1270.

86 Stearns V, Davidson NE, Flockhart DA. Pharmacogenetics in the treatment of breast cancer. Pharmacogenomics J 2004:4:143-153.

87 Newman LA, Kuerer HM, Hunt KK et al. Response to induction chemotherapy in black and white patients with locally advanced breast cancer. Breast J 2000;6:242-246. 
88 Hershman D, Weinberg M, Rosner Z et al. Ethnic neutropenia and treatment delay in African American women undergoing chemotherapy for early-stage breast cancer. J Natl Cancer Inst 2003;95:1545-1548.

89 Breen N, Wesley MN, Merrill RM et al. The relationship of socio-economic status and access to minimum expected therapy among female breast cancer patients in the National Cancer Institute Black-White Cancer Survival Study. Ethn Dis 1999;9:111-125.

$90 \mathrm{Chu} \mathrm{K}$, Lamar C, Freeman H. Racial disparities in breast cancer survival rates: separating factors that affect diagnosis from factors that affect treatment. Cancer 2003;97:2853-2860.

91 Roach M 3rd, Cirrincione C, Budman D et al. Race and survival from breast cancer: based on Cancer and Leukemia Group B trial 8541. Cancer J Sci Am 1997;3:107-112.

92 Fisher ER, Redmond C, Fisher B et al. Pathologic findings from the National Surgical Adjuvant Breast and Bowel Projects (NSABP). Prognostic discriminants for 8-year survival for node-negative invasive breast cancer patients. Cancer 1990;65:2121-2128.

93 Dignam JJ. Differences in breast cancer prognosis among African-American and Caucasian women. CA Cancer J Clin 2000;50:50-64.

94 Dignam JJ. Efficacy of systemic adjuvant therapy for breast cancer in African-American and Caucasian women. J Natl Cancer Inst Monogr 2001:36-43.

95 Albain KS, Unger JM, Hutchins LF et al. Outcome of African Americans on Southwest Oncology Group (SWOG) breast cancer adjuvant therapy trials. San Antonio Breast Cancer Symposium, San Antonio, TX, 2003;21.

96 Van Ness PH, Kasl SV, Jones BA. Religion, race, and breast cancer survival. Int J Psychiatry Med 2003;33:357-375.

97 Henderson PD, Fogel J. Support networks used by African American breast cancer support group participants. ABNF J 2003;14:95-98.

98 Henderson PD, Gore SV, Davis BL et al. African American women coping with breast cancer: a qualitative analysis. Oncol Nurs Forum 2003;30:641-647.

99 Michalec B, Van Willigen M, Wilson K et al. The race gap in support group participation by breast cancer survivors: real or artifact? Eval Rev 2004;28:123-143.

100 Farmer BJ, Smith ED. Breast cancer survivorship: are African American women considered? A concept analysis. Oncol Nurs Forum 2002;29:779-787.

101 Newman L, Jackson K. Breast cancer in African American women: the evolution of the Sisters Network, Inc., A National African American Breast Cancer Survivor Advocate Organization. Breast Diseases: A Yearbook Quarterly 2002;14:122-124.

102 Health Insurance Coverage: 2001, Volume 2003. U.S. Census Bureau, 2001.
103 Boyer-Chammard A, Taylor TH, Anton-Culver H. Survival differences in breast cancer among racial/ethnic groups: a population-based study. Cancer Detect Prev 1999;23:463-473.

104 Burri SH, Landry JC, Davis LW. Breast conservation is an effective option in Black, medically indigent patients. J Natl Med Assoc 2002;94:453-458.

105 Connor CS, Touijer AK, Krishnan L et al. Local recurrence following breast conservation therapy in African-American women with invasive breast cancer. Am J Surg 2000;179:22-26.

106 Nicolaou N, Fowble B, Hanlon A. The impact of regional lymphatic irradiation and of the extent of axillary lymph node dissection on regional control in patients with early-stage, node-positive breast cancer, treated with breast-conserving therapy. Proc Am Soc Clin Oncol 1999;18:266.

107 Velanovich V, Yood MU, Bawle U et al. Racial differences in the presentation and surgical management of breast cancer. Surgery 1999;125:375-379.

108 Arnold RE, Frykberg ER, Kilkenny JW et al. Trends in surgical treatment of breast cancer at an urban teaching hospital: a six-year review. Am Surg 1998;64:107-111.

109 Muss HB, Hunter CP, Wesley M et al. Treatment plans for black and white women with stage II node-positive breast cancer. The National Cancer Institute Black/White Cancer Survival Study experience. Cancer 1992;70:2460-2467.

110 Shiao Y, Chen V, Scheer W et al. Racial disparity in the association of $\mathrm{p} 53$ gene alterations with breast cancer survival. Cancer Res 1995;55:1485-1490.

111 Guillemette C, Millikan R, Newman B et al. Genetic polymorphisms in uridine diphospho-glucuronosyltransferase 1A1 and association with breast cancer among African Americans. Cancer Res 2000;60:950-956.

112 Mehrotra J, Ganpat M, Kanaan Y et al. Estrogen receptor/ progesterone receptor-negative breast cancers of young African American women have a higher frequency of methylation of multiple genes than those of Caucasian women. Clin Cancer Res 2004;10:2052-2057.

113 Chen Z, Wu AH, Gauderman W et al. Does mammographic density reflect ethnic differences in breast cancer incidence rates? Am J Epidemiol 2004;159:140-147.

114 Porter PL, Lund MJ, Lin MG et al. Racial differences in the expression of cell cycle-regulatory proteins in breast carcinoma. Cancer 2004;100:2533-2542.

115 Millikan RC, Player J, De Cotret AR et al. Manganese superoxide dismutase Ala-9Val polymorphism and risk of breast cancer in a population-based case-control study of African Americans and whites. Breast Cancer Res 2004;6:R264-R274.

116 Li Y, Millikan RC, Bell DA et al. Cigarette smoking, cytochrome P4501A1 polymorphisms, and breast cancer among African-American and white women. Breast Cancer Res 2004;6:R460-R473.

117 Jones BA, Kasl SV, Howe CL et al. African-American/White differences in breast carcinoma: p53 alterations and other tumor characteristics. Cancer 2004;101:1293-1301. 